Kristin Gundersen

Master. Department of teacher education and school research, University of Oslo

Hanne Hellem Kristiansen

Master. Department of teacher education and school research, University of Oslo

Astrid G. Samdal

Master. Department of teacher education and school research, University of Oslo

Jon Magne Vestøl

Associate professor. Department of teacher education and school research, University of Oslo

\title{
Religion in Textbooks and among Young Buddhists, Hindus and Muslims : A Comparative Study
}

\begin{abstract}
This article presents three studies of religious beliefs and practices among young Norwegian Muslims, Buddhists and Hindus related to the presentation of these religions in religious education textbooks. Drawing on analyses of textbook presentations and group interviews with young informants from the three religions, the studies show that there are similarities as well as divergences between the textbook presentations and the descriptions given by the informants. By showing how textbooks may emphasize aspects of religions that the informants find marginal or exotic, this article adds to the understanding of the complex challenges posed to religious education by an increasingly multicultural context.
\end{abstract}

\section{Introduction}

During the last decades, criticism has been raised against the way religions are presented in religious education in schools (Jackson, 1997, 2004; Jackson \& Nesbitt, 1993; Nicolaisen, 2009, 2012, 2013; Moulin, 2011). Religious education tends to present religions as monolithic traditions and may run the risk of stereotyping religion, and thereby obscuring the variety of beliefs and practice found among religious adherents locally and worldwide.

Drawing on empirical data from three Norwegian studies, this article focuses on the relationship between textbook presentations of religions and 
understandings of religions among religiously active young Norwegian Muslims, Hindus and Buddhists (Gundersen, 2013; Kristiansen, 2013; Samdal, 2013). Through analyses of how religion is displayed in textbooks and expressed by young adherents, the studies address the following research question:

How do young Norwegian Muslims, Hindus and Buddhists understand and express their religious beliefs and practices, and how do these expressions relate to textbook presentations of the three religions?

Focusing primarily on the upper secondary level, the studies have interviewed young people aged from 15 to 22 and have analysed textbooks produced for the compulsory, secular and multi-faith subject "Religion and Ethics" which is taught in the last year of Norwegian upper secondary school (RE-curriculum, 2006). While Islam is a compulsory topic together with Christianity, both Buddhism and Hinduism are among the alternatives for the third optional religion to be chosen for study. Among the issues to be covered in the subject are key aspects of the religion, such as religious texts, denominations, aesthetical and ritual expressions, gender issues and the relationship with other religions.

\section{Theoretical perspectives and previous research}

\section{The Warwick project and the interpretive approach}

Based on the perspectives on religion developed by Robert Jackson and the Warwick project $(1997,2004)$, this article understands religion as a three-level phenomenon including a level of tradition, an individual level, and an intermediary group level. The understanding of religion developed by Jackson is based on perspectives from ethnography and anthropology as well as empirical research on religious life in local British communities. In their first study, Hindu Children in Britain (Jackson \& Nesbitt, 1993), Jackson and Eleanor Nesbitt showed how Hindu children in Britain understand their religious tradition, and how Hindu traditions change and develop in a British context. Based on several studies, Jackson and Nesbitt have developed a critical attitude to presentations of "world religions" as homogenous systems of beliefs with an unchanging core.

In Jackson's interpretive anthropology-inspired approach a distinction is made between three elements; representation, reflection and interpretation (Jackson, 2011). Representation refers to how religious traditions are presented by adherents and by media, textbooks and other sources (Jackson, 2011: 191). Such representations are found on the level of tradition, as well as on the individual and group levels mentioned above. The level of traditions relates to presentations of religion on an overall level, where all denominations and cultural manifestations of a religion are integrated in a general description of core issues (Jackson, 1997: 49; 2011: 191). The group level refers to positions taken by denominations, sects, or ethnic groups associated with the religious 
tradition, while the individual level refers to the practices and beliefs of individual adherents.

Based on this three level scheme, textbook presentations may be understood as representations on the level of tradition, while utterances from young informants may be seen as representations on an individual level, possibly relating to a group level.

The Warwick project has developed an educational framework in which the three levelled representation of religion is subject to phases of reflection and interpretation. In this way pupils reflect on how traditions presented in textbooks may differ from individual experiences of religious practice and beliefs (Jackson, 2011: 192). Educational resources have been developed that facilitate pupils' reflection on how their own pre-understandings and possible prejudices may influence their perceptions of religious traditions (Everington, 1996; Robson, 1995).

In the studies reported in this article, the interpretive aspect is to some extent activated in the interview settings in which the young adherents are invited to reflect on how textbooks present their religious traditions. The main emphasis in this study is, however, on how religion is represented as tradition, and as individual experience in textbooks and among the informants.

\section{Research on young peoples' relationship to religion}

During the two decades since the launch of the Warwick project, additional research has provided extended information concerning representations of Hinduism, Islam, Christianity and Judaism, while less attention so far has been paid to Buddhism.

As briefly mentioned above, the first studies of diaspora-Hindus by Jackson and Nesbitt (1993) showed how religious tradition, practice and beliefs among British Hindu immigrants has changed as a result of multicultural development, and how Hindu children encounter a variety of cultural practices. The children showed a more complex understanding of religion compared to presentations found in the textbooks where Hinduism was described as a religion with specific doctrines and an integrated set of attitudes and beliefs. In later studies, Nesbitt has included young informants from other religious traditions, among them Sikhs, and she has also reported on the experiences of pupils from mixed-faith families (Nesbitt, 2004; Arwick and Nesbitt, 2011). Additional studies report how even Christian and Jewish teenagers experience the stereotyping of their religious practice and beliefs in the RE classroom (Moulin, 2011).

Turning to the Norwegian context, the most extensive works on Hinduism are Tove Nicolaisen's studies on Hindu children's relationship to religion and religious education (Nicolaisen, 2009, 2012, 2013). Nicolaisen has shown how Hindu children understand and practice their religion in ways that challenge what she labels "the RE-normality" of the classroom, where religions are 
presented as separate, definable entities that are distinctly separate from the secular world. According to Nicolaisen, this notion of religion is a Western construction, based on a framework derived from Christianity and from philosophical traditions stemming from the European enlightenment (Nicolaisen, 2013: 171). Demonstrating the lack of universality in this understanding of "world religions", Nicolaisen has argued that anthropologically based studies should be integrated in religious education to make the presentations more recognizable to pupils (Nicolaisen, 2013: 289).

Based on interviews with adolescents with a North-Indian background, Ram Gupta (2006) concluded that these young Hindus talked about religion in ways that were inspired by Norwegian culture, while their identity to a great extent was related to being Hindu. Even if they lived and acted according to culturally inherited religious customs, they had developed their own personal ways of believing. According to Gupta, the religious practice of young Hindus in Norway differed in certain respects from Hindu practice in a North-Indian context.

The findings of Gupta and Nicolaisen are also confirmed by the Norwegian researcher Knut A. Jacobsen (2007) who has described how Tamil identity is more important than Hindu identity to immigrants with a Sri Lankan background. According to Nicolaisen (2013), such findings challenge the way religious education focuses on religion as a primary marker of identity. Nicolaisen therefore argues that religious identity is given too much emphasis compared with other ways in which pupils choose to express their selfunderstanding.

Studies of the role of Islam among young Norwegians have been undertaken by Sissel Østberg (Østberg, 1998, 2003). Drawing on Jackson's approach, Østberg has studied Norwegian-Pakistani's opinions on identity, Islam and ethnical belonging, and how they construct and develop identity in a multicultural Norwegian context. In her publication from 2003, Østberg shows how religious identity and understandings of religion may change during the developmental processes from childhood to adolescence. Østberg has emphasized that her informants did not differ substantially from their nonMuslim friends, and that the existing differences were not strong enough to stop integration. While her informants took their parents' views for granted during childhood, they developed more conscious and critical positions during upper secondary school, negotiating with a range of people and developing their own interpretations of Islam (Østberg, 2003: 163-164).

Other researchers have contributed to the understanding of being a Muslim in a Norwegian context (Leirvik, 2002, 2007; Strandhagen, 2008; Vogt, 2000). Based on interviews with six young Shia Muslims and field work in Oslo, Strandhagen's master thesis describes how young Shia Muslims reflected on central aspects of their religious identity, and how this can be interpreted in light of theories on trans-nationality and modernity. 
Oddbjørn Leirvik has put particular emphasis on the issue of religious dialogue, but he has also discussed the relationship between religion and culture. According to Leirvik, religion does not exist in pure form, but only as religious practice coloured by cultural context (Leirvik, 2007: 44). While some Muslims distinguish between what is "Muslim" (practice) and what is "Islamic" (normative interpretations), others do not emphasize such distinctions. Leirvik argues that distinctions between cultural and religious aspects are more emphasized by second and third generation immigrants, as these generations try to distance themselves from traditions related to female circumcision, forced marriage and patriarchal attitudes. In this respect, Leirvik argues in a direction similar to Østberg, who emphasizes how religion may be seen as normative and true, while cultural traditions may be abandoned or changed (Østberg, 2003).

In his dissertation on religious education and "identity management", Lars Laird Iversen (2012) shows how Muslim identity in the classroom is a negotiation between the "blackboard facts" of the school subject and varying "involved facts" among the Muslim pupils. He argues that religious identity is material and contemporary, and involves everyday experience.

In the cross-country REDCo project financed by the European Union, in which secondary school pupils from Norway participated, the majority of Norwegian informants showed a weak or lacking interest for religion, and regarded identity as related to personal interests rather than to religion or life view (Lippe, 2011). In another study, Marie von der Lippe showed that religious understanding and practice among young Norwegians is complex and diverse, not only across religious traditions, but also within these traditions (Lippe, 2008).

\section{Research on textbooks}

As mentioned previously, Nesbitt (1998) has documented how textbooks tend to generalize religions, and how this in particular affects the understanding of Hinduism. Nesbitt has argued that such generalizations may have a marginalizing effect on pupils who identify themselves as Hindus, but who do not share the emphasis that is put on certain "Hindu" norms and principles in the textbooks.

In a Scandinavian context, textbook presentations of religion have been the focus of several studies. Skrunes (2010) refers to studies describing lack of impartiality and objectivity in textbook descriptions of religions. While studies of Swedish textbooks by Härenstam ("skolboksislam") has documented similar tendencies, Härenstam has also shown how textbooks have changed for the better during the time elapsed between his dissertation and his later report (Härenstam, 1993, 2006).

Thobro (2008) analyzed presentations of Hinduism and Buddhism in upper secondary school textbooks and found that both religions were described in an 
essentialist way. According to Thobro, Hinduism was closely linked to essences like caste and reincarnation and the stereotypic picture of the ascetic, while Buddhism was linked to the historical Buddha and his teachings, leaving the impression that subsequent developments, for instance the later Buddhist understanding of the concept of god, represent a degenerations of, or a watering down of the "Buddhist essence".

Although the studies mentioned in the sections above have pointed out discrepancies between religious practices and the way religions are presented in religious education and in textbooks, more research is required to display the contextual variety of such issues. In particular, it is important to cover religions, such as Buddhism, that have previously been overlooked in this respect. The purpose of this article is to contribute to this.

\section{Method}

Being qualitative and comparative by nature, the purpose of the three studies has been to shed light on how young Muslims, Buddhists and Hindus understand their religious beliefs and practices compared with the ways their religions are described in the textbooks.

Included in the textbook analyses were the textbooks for upper secondary religious education that were available at the time of the interviews (Aronsen, Bomann-Larsen, \& Notaker, 2008; Heiene, Myhre, Opsal, Skottene, \& Østnor, 2008; Kvamme, Lindhardt, \& Steineger, 2008). A revised version of one of the textbooks that was published after the completion of the study (Kvamme, Lindhardt, \& Steineger, 2013) has been consulted in cases where informants have raised criticism against this specific book. Chapters on Islam, Buddhism and Hinduism in all three textbooks have been analysed. Material from the textbooks' websites has not been included, except for the website presentation of Hinduism at the website of Eksistens (Gyldendal-Eksistens, 2013) since the printed textbook did not include a chapter on this religion.

As displayed in Table 1, each of the three studies included a group interview. The informants were recruited through contact with relevant religious groups and by the help of informants who recruited others. As the recruitment of informants turned out to be difficult, it was decided to carry out the interviews even though the optimal sample had not been achieved. 
Table 1: The informants participating in the group interviews

\begin{tabular}{|l|l|l|l|}
\hline & Study 1 & Study 2 & Study 3 \\
\hline Religious affiliation & Shia Islam & $\begin{array}{l}\text { Vietnamese } \\
\text { Buddhism }\end{array}$ & Tamil Hinduism \\
\hline $\begin{array}{l}\text { Number of } \\
\text { informants }\end{array}$ & 2 females, 3 males & 1 female, 2 males & 4 females \\
\hline $\begin{array}{l}\text { Name and gender } \\
\text { (f/m) } \text { of informants }\end{array}$ & $\begin{array}{l}\text { Amina (f), Ismal (m), } \\
\text { Yosef (m), Malak (f), } \\
\text { Muhammed (m) }\end{array}$ & $\begin{array}{l}\text { Bob (m), Lusi (f), } \\
\text { Nick (m, novice). }\end{array}$ & $\begin{array}{l}\text { Hamshika (f), Nelani (f), } \\
\text { Pavinika (f), Sabitha (f) }\end{array}$ \\
\hline Age & $17-20$ & $15-17$ & $17-22$ \\
\hline
\end{tabular}

In study 2, the available informants turned out to be slightly younger than desired, and in study 3, it was difficult to recruit male informants. However, the analysis has not displayed any particular bias related to these differences. Some of the informants were attending religious education in upper secondary school, while others had graduated or had not yet had any experience with the subject at this level of schooling.

Tamil Hindus were selected for the interview to see whether they could relate to the textbook presentation of Hinduism, even though the books focus primarily on the north Indian Hindu tradition. There might have been less discrepancy between the perspectives if Hindus with a north Indian background had been interviewed. However, since the previously mentioned studies show how some textbooks of religious education present religions as monolithic traditions in ways that exclude the complexity of religious practice in local religious communities, it was decided to give the Tamil Hindus a voice in this study.

Similar considerations were made concerning the choice of Shia Muslims who are a minority, globally as well as in Norway. The experiences of Shias therefore represent a double minority position. The Vietnamese Buddhists belong to a religious tradition that is usually given little public attention. The experience of the Buddhist informants may therefore add to our understanding of the variety of experience among religious minorities.

To protect the anonymity of the respondents, the amount of information about the participants has been restricted and pseudonyms are used, although the fact that one of the informants in study 2 was as a Buddhist novice has been made explicit. All participants were informed and consent gained from both informants and parents. Necessary permissions were also gained for all studies from Norwegian Social Science Data Services (NSD).

For practical reasons all three interviews were located to the campus of a local academic institution. All the interviews were carried out during February 2013 using digital voice recordings that were subsequently transcribed and anonymized. Group interviews were chosen since such interviews may stimulate 
sharing of experience among the respondents and also may counter-balance the possible asymmetry between interviewer and interviewees.

Following a shared semi-structured guide, the three interviews focused on the same themes. In its first part, the interview guide focused on questions concerning value preferences and religious affiliation at a more overall level. In the main part, a range of religious dimensions were addressed, such as practices, aesthetical aspects, texts, beliefs, community, experience and ethics, while the last part of the interview invited the informants to comment on textbook excerpts. Due to time limitations, the respondents in study 1 gave their comments related to the last part via e-mail after the interview.

The analyses of the interviews were carried out separately. Focusing on the content or the substance of the interviews (Johannessen, Tufte, \& Kristoffersen, 2006; Skrunes, 2010), a two-stage procedure of analysis was followed, including an "open" coding process and a subsequent coding related to the main issues emphasized in the interview guide.

As the analyses of the studies have been published separately as master dissertations (Gundersen, 2013; Kristiansen, 2013; Samdal, 2013), this article presents the three studies in a comparative perspective, focusing on findings that contribute to a more overarching understanding of the issues.

\section{Results}

While the textbook presentations were characterized by historical, geographical and more academic approaches, the young informants had a personal approach to religion. This personal approach was characterized by their effort to reconcile the traditions from their parents' country of origin with Norwegian culture.

The studies show that the young informants rarely expressed themselves by using religious terms and concepts commonly highlighted in academic textbooks. With the exception of the word "karma", the young Hindus did not use religious concepts such as "dharma", "moksha", "atman" and "samsara". The young Buddhists used a few more religious academic concepts, partly in Vietnamese. The Muslim informants used designations such as "Karbala" and "Ashura festival", but they did not use any other traditional religious terms.

The informants mainly portrayed their relationship to religion within the framework of their everyday context. They linked existential questions and the meaning of life to everyday matters such as education, exercise, music, family and friends, which were important elements in their lives.

Hindu Sabitha verbalized this personal approach: "I do not need to, in a way, go to the temple to pray every day. But as long as I [...] believe in God and have God in my heart, then it works out well". Buddhist Bob talked about the importance of karma in his daily life: "I think about karma when I do something, think something or say something - every day". To Muslim Amina, 
God was the nucleus of life: "The basic of faith is a faith in God, faith in Him, to start the day reminding yourself that God exists and that you return to Him one day."

By emphasising the individual experience and community-oriented perspectives, the informants expressed a notion of religion different from the more tradition-oriented approach in the textbooks. Some of the more specific differences between textbook presentations and the interviews will be further elaborated below.

\section{Adherence to tradition}

The textbook presentations of Hinduism, Buddhism and Islam were based on a historical-systematic approach to religions. The religions were described as distinct and separate, and as including various strands and subgroups. Shia Islam and Mahayana Buddhism, as two of the groups of informant were linked to, were portrayed as denominations within Islam and Buddhism respectively, while Tamil Hinduism, which informants in study 3 were connected to, was not mentioned in the textbook chapters devoted to Hinduism, although "shivaism" the denomination most Tamil Hindus belong to - was mentioned in one of the textbooks.

Even if the Muslim and Buddhist informants seemed to identify with the religion and the main denomination to which they belonged, some important nuances should be mentioned. While the Buddhist novice Nick recognized and used the denominational terminology, the other Buddhists did not emphasize the more detailed distinctions beyond the Theravada-Mahayana. As stated by Bob: "We sort of have no denomination. We simply are [...] We are everything in a way."

The Shia Muslim informants normally identified themselves as "Muslims" and used "Shia" only when further specification was needed. Muslim Yosef explained: "I ask them if they know the difference. If they know I will tell them, but usually it is sufficient to say that I am a Muslim." The Muslim informants were, nevertheless, critical to the framing of the presentations of Islam in the textbooks because they found that the textbooks favoured Sunni Islam.

According to the Tamil informants, it was misleading to describe Hinduism as a monolithic religion, especially since the books were found to be biased towards North Indian Hinduism, and thus ignored the peculiarities of the Tamil tradition. The informants were not familiar with the designations of the denominations that were presented in the textbooks, such as "vishnuism", "shivaism" and "shaktism" - possibly because they never used the term "shivaism" at home, but rather "the Tamil tradition".

Although the Hindu informants understood themselves as Hindus, they also emphasized how their religious practice and beliefs transcend the border of a singular religious tradition. They did not recognize the textbook presentations of Hinduism as a distinct and "defined" religious tradition, and maintained that the 
textbooks underestimated the diversity and complexity of Hinduism. The informants also argued that the various portraits of gods should be understood as expressions of the one God, and explained how they related to God on a deeply personal level. Arguing that the textbooks were not able to portray Hinduism's inclusive attitude towards other religions, the informants emphasized that they had statues of Jesus, Mary and Buddha in their prayer rooms, attended church during Christmas and had Christian friends. Hamshika explained how it was part of their culture to "mix" religious traditions: "It is God, isn't it. And we think of so many gods, so why not Jesus? It is just one more."

\section{The importance of the temple and the mosque}

While both the textbooks and the informants described the importance of the temple and the mosque, the textbooks placed more emphasis on religious buildings as places of ritual practice, as well as the architectural and artistic aspects of the exterior and interior of the buildings.

In the interviews, there were also references to rituals such as prayer in the mosque and temple festivals, but the focus of the informants was mainly on the significance of these rituals for the social and religious community to which they belonged, and for their own identity formation. While the Muslim and Buddhist informants focused on the mosque and the temple respectively, the young Hindus considered the personal prayer at home as the most important aspect of their religious practice and beliefs. Even if Hindus may value prayer at home on an equal level with prayer in the temple, the informants attributed their practice to a busy Western lifestyle. Hindu Nelani explained how they negotiated a personal intercultural lifestyle:

You have to adjust to the country in which you live. If we had been at Sri Lanka, we would have followed the tradition in all detail. [...] When you live here, there are a lot of things to be taken into consideration. Is it important to be a Hindu, or should you try to include both things? To find a balance, that's what is important to me at least.

\section{Codes of conduct and social norms}

Differences between informants and textbooks also emerged regarding codes of conduct and social norms. In their presentation of Buddhism, the textbooks focused on the monks' codes of conduct and ways of life, while the young informants highlighted the importance of religion in their daily lives.

Buddhist informant Bob used a metaphor to explain his experience of the karmic law: "If you plant a seed and [...] do not water it, then it will not grow. [...] But if you start watering it, then it will grow. [...] If we help the seed [...] by doing good things [...] it will help us achieve a better life later on."

While this understanding of karma was not contradicted in the textbook presentations, the informants found it misguiding when the textbook described Buddhist lifestyle with Buddhist monasticism as a point of reference. Buddhist 
Lusi stated: "I think that in these textbooks it is presented as very restricted [...] compared to how it really is practiced here in Norway." Even though one of the informants, Nick, was a novice in the temple, it was not the monks' norms that characterized the daily lives of the other Buddhists.

While the textbooks seemed to emphasise the karmic effects related to the future, the Hindu informants focused more on the present life. Nelani said: "I think more about karma here and now, that you have to be a good person." And Hamshika said that she sometimes yells at her mother and afterwards thinks that "OK, my daughter will probably do the same thing towards me."

The textbook descriptions of the common Islamic rituals resembled the experience and practice of the informants, but the informants also extended the implications of the practice as when the daily prayer was described by Muslim Yosef as a source of moral action: "Islam is more than just performing the five daily prayers. Because the Koran tells what the prayer does to the one who prays, how it prevents the one who prays from doing immoral deeds."

\section{Individual variations}

As the textbooks mainly focused on the general and common traits of the three religions, they gave little information about individual variations in the practice and beliefs of the religions and did not emphasize such variations.

There were, however, individual variations among the informants in the ways they approached religious practice and beliefs. While the Buddhist Lusi focused on how she practiced her religion, the Buddhist Nick emphasized the understanding of the religion. As a Buddhist novice, Nick had a precise understanding of mantras, while the two other young Buddhists seemed to be less familiar with this aspect of the religion. Nick also seemed to be more familiar with religious texts than the two other informants.

Some of the informants described how they might choose different angles or perspectives in their interaction with others. For instance, Muslim Muhammed described how he tended to discuss with non-Muslims on a more general level, while he focused more on the group level (relationship between Sunni and Shia) when he talked with other Muslims.

Variations in living conditions and cultural context influenced the informants' religious practice. The young Hindus described how they had developed a personal and individual form of belief and religious practice that seemed to be different from what is found among the older generation of immigrants and among Hindus in the land of origin of the immigrants.

\section{Critical remarks on textbook presentations}

In the textbook presentations of the religions, the focus was mainly on specific beliefs, rituals, texts and traditions, but as a rule the textbooks did not explain or 
problematize the selection of issues or the implications their choice of perspective might have for the presentation of the religion.

During the interviews, the informants made critical remarks about the textbook presentations of religions. As previously mentioned, the Buddhist informants criticized how the textbooks focused on Buddhism as a monk religion, neglecting the practice of ordinary Buddhists. Similar criticism was raised by Muslim informants concerning the way textbooks favoured Sunni Islam at the expense of Shia Islam when they related the presentation of all the basic tenets of Islam to the Sunni Islamic tradition, giving the impression that Sunni Islam is the "normal" variant.

In similar ways the Hindu informants criticized the textbooks for focusing on North Indian Hinduism, downplaying Hinduism in Sri Lanka and other countries. The informants pointed out that Hindu places of pilgrimage are found also in Sri Lanka, not only at the Indian subcontinent.

On a more detail level, the Buddhist informants criticised insufficient explanation of a photograph of the Samsara wheel. The Hindu informants commented on a photograph in the textbook I samme verden (Kvamme et al., 2008: 216) showing Hindu holy men celebrating the Kumbh Mela festival. Commenting on this photo, the informant Nelani said that it "gives the impression that a group of lunatics are sitting there; no explanation is given." This textbook has been revised and republished since the time of the interviews, and the photo has been given even more space in the revised version (Kvamme et al., 2013: 180).

Evenly critical was the reaction among the Muslim informants against three pictures in the textbook Eksistens showing blood-stained men who have whipped themselves on the day of Ashura (Aronsen et al., 2008: 172, 179, 209). The Muslim informants also criticized a table found in the textbook I samme verden presenting the hudud punishment (Kvamme et al., 2008: 157). Even if the textbook made clear in the main text that use of this punishment is controversial within Islam, the informants held that the textbook made this punishment stand out graphically as an important part of Islam. In the eyes of the informants this was highly problematic, since, according to Yosef "one or two per cent of all Muslims in the world believe in this." In the revised edition of the textbook, the table has been removed (Kvamme et al., 2013).

To the Hindu informants, the focus on the caste system in the textbooks was a somewhat similar problem. The informants argued that the caste system was given too much emphasis in the textbooks in contrast to how they experienced their religion, as Nelani emphasised: "You become so upset, because this is not what my religion represents."

Through their critical reflections on specific aspects of the textbook presentations the informants showed how textbooks may deal with religion in ways that emphasize the exotic and promote marginalization of religious groups. According to the informants, the textbook presentations included elements that 
made the religions of the informants look strange and peculiar, and also made it hard to understand how these religions fit into the lives of young people in a Norwegian context. By downplaying the religious life and religious group adherence of the informants, the textbooks reduced the potential of religious education to increase pupils' understanding of religious identity and practice among their mates.

The interviews did, however, also display more positive evaluations of the knowledge presented through textbooks and religious education. The Hindu informants pointed out that religious education and textbooks gave them knowledge about how their religion is understood and described from an outside perspective. Sabitha said: "I really think that textbooks should be a bit more thorough, because I do learn Hinduism [...] In fact, the first time I started to understand quite a bit, that came from school." And Buddhist Lusi emphasized the value of religious education more in general. "Since I have been raised as a Buddhist [...] if I had not learned it in school I would not have known anything about other religions. Then I would only have known about my own belief and would not have understood why people believe differently."

During the interviews, some of the informants suggested how the religious dimension of individuals might be included in religious education. NorwegianTamil Nelani emphasized that textbook presentations should give more examples of religion as experienced from the insider's perspective. Shia Islamic informants suggested that pupils might be used as sources of knowledge to provide supplying information. Such use of pupils as representatives of religious traditions was acclaimed by several of the informants.

To sum up, the three studies showed how textbook presentations of religions are challenged by the young informants. While the textbooks focused on general characteristics of religions as tradition, the informants communicated religion as situated and experienced. In this way, the young Muslims, Buddhists and Hindus demonstrated how textbooks struggled to cope with the diversity of religious practice and belief and with the experiences of religious minority positions in a Norwegian context.

\section{Discussion}

Through this article it has been demonstrated that there is a multifaceted relationship between religion as it is presented in textbooks and religion as it is presented among young informants. While the textbook presentations and the interviews overlap in certain ways, it also becomes evident that they display different or even conflicting perspectives on the religions they describe. Textbooks usually give a systematic and monolithic presentation of religion that leaves an impression of religions as distinct and clearly defined traditions. The 
informants on the other hand, reflect from a position of religious experience and practice subject to competing sources of influence; their own religious experience versus the classroom presentations of religions as well as cultural traditions from their parents' home country versus the cultural traditions of Norway.

In this way, the three studies confirm findings in previous studies that young people from immigrant groups are subject to cultural tensions. While they have an established relationship to family traditions (Østberg, 2003), they also seek to find a balanced relationship to Norwegian culture (Gupta, 2006; Nicolaisen, 2013). The studies also confirm the tendencies pointed out by Nicolaisen that textbooks present religions in exotic, stereotypic and marginalized ways. Exoticisms and marginalization in textbook presentations are particularly highlighted in the studies on Islam and Hinduism.

The study on Hinduism shows how young people adjust their religious practice to a Western way of living. This implies that community aspects of ritual practice are downplayed in favour of a more individual religious practice (Gupta, 2006). Nicolaisen (2013) has previously shown how the notions of God among Hindu children are more complex than what is described in the textbooks, and that one child in particular expressed an advanced notion of God. The study on Hinduism demonstrates how all the informants transcended concrete notions of God and developed a more expansive understanding of God. By showing this, the study displays possible processes and strategies in the development these young people undergo towards a more independent belief.

Since it covers a part of religious education that previously has been little studied, the study on Buddhism shows how the Buddhist informants in ways similar to the other informants found both familiar and unfamiliar aspects in the textbook presentations. While the Buddhist novice showed a strong relationship with Buddhism as a defined religious tradition, the two other Buddhist informants expressed more individual points of view.

To sum up, the three studies showed that there is a need to develop and strengthen the understanding of how religious beliefs and practices from other cultures are contextualized within a Norwegian setting. Of particular interest is how religion develops and changes in processes of socialization from childhood to adolescence, and what happens when young people from immigrant families are challenged to stand out as representatives of their religious practice and beliefs when this religion is portrayed as exotic and marginalized by their surroundings.

In this respect, the studies underpin the need for a more nuanced understanding of religion within the context of religious education, as argued by Robert Jackson (1997, 2004). The understanding of religion is closely related to the understanding of the purpose of religious education. One aspect is the presentation of facts, to describe religions in a way that is as accurate as possible in including both systemic and more individual dimensions. Another is to 
develop an understanding of, and respect for, religion as stated in the objectives of the syllabus: "Religious education should contribute to knowledge on and respect for various religious, views on life and ethical standpoints in local, national and global perspectives" (RE-curriculum, 2006). Such respect requires a presentation of religions that is recognized by pupils that identify with the religious tradition and understood by the pupils who distance themselves from religion.

Due to the particularity and the contextual limitations of individual religious experiences, pupils' individual positions may be challenged through the variety of practices and beliefs presented in religious education. Despite the criticism raised against textbooks and religious education, this article does not suggest that the content of religious education should be entirely determined by pupils. During the interviews, the informants also expressed positive evaluations of religious education as a source of expanded and deepened knowledge.

What the studies presented in this article have shown is that in order to develop a prosperous integration of tradition-oriented and individual perspectives on religion, it may be of particular importance to understand agerelated changes in religious practices and beliefs and to handle minority issues in ways that avoid the pitfalls of marginalization and exoticism. More research will be needed to cover the individual and group-related variations related to such issues. It would also be of interest to conduct action-oriented classroom research where ethnographical research data are used as additional sources of knowledge in religious education to explore how the use of such material contributes to pupils' understanding of religion.

\section{References}

Aronsen, C. F., Bomann-Larsen, L., \& Notaker, H. (2008). Eksistens. Religion, etikk, livssyn, filosofi. Oslo: Gyldendal.

Arwick, E. \& Nesbitt, E. (2011): Religious education in the experience of young people from mixed-faith families. British Journal of Religious Education, 33(1), 31-45

Everington, J. (1996). Meeting Christians. Book Two. Oxford: Heinemann Educational Publishers.

Gundersen, K. (2013): Den unge buddhistens forhold til tro, religiøs praksis og livstolkning og til loerebøkers fremstilling av buddhisme [The young Buddhists' relationship to faith, religious practice and lifeview - and to textbook presentations of Buddhism]. Master Thesis. Oslo: University of Oslo.

Gupta, R. (2006). Being a Hindu in Oslo. Change and Continuity. Oslo: Institutt for sammenlignende kulturforskning.

Gyldendal-Eksistens. (2013). Eksistens nettsted. Retrieved 06.11, 2013, from $\mathrm{http}: / / \mathrm{mml}$.gyldendal.no/flytweb/default.ashx?folder=1936\&redirect_from_tibet=true

Heiene, G., Myhre, B., Opsal, J., Skottene, H., \& Østnor, A. (2008). Tro og tanke. Religion og etikk for den videregående skolen. Oslo: Aschehoug.

Härenstam, K. (1993). Skolboks-islam : analys av bilden av islam i lärobøcker $i$ religionskunskap. Göteborg: Göteborg Universitet. 
Härenstam, K. (2006). En granskning av hur religion/trosuppfattning framställs $i$ ett urval av läroböcker. Underlagsrapport till Skolverkets rapport "I enlighet med skolans värdegrund?". Retrieved 06.11, 2013, from http://www.skolverket.se/polopoly_fs/1.22923!/Menu/article/attachment/Religion.pdf

Iversen, L. L. (2012): Learning to be Norwegian. A case study of identity management in religious education in Norway. Münster: Waxmann

Jackson, R. (1997). Religious Education - an interpretive approach. London: Hodder and Stoughton.

Jackson, R. (2004). Rethinking Religious Education and Plurality. London: RoutledgeFalmer.

Jackson, R. (2011). The interpretive approach as a research tool: inside the REDCo project. British Journal of Religious Education, 33(2), 189-208.

Jackson, R., \& Nesbitt, E. (1993). Hindu Children in Britain. Oakhill: Trentham Books.

Jacobsen, K. A. (2007). Indias religioner - Jainismen, Buddhismen, Hinduismen, Sikhismen. In I. S. Gilhus \& L. Mikaelsson (Eds.), Verdens levende religioner. Oslo: Pax.

Johannessen, A., Tufte, P. A., \& Kristoffersen, L. (2006). Introduksjon til samfunnsvitenskapelig metode. Oslo: Abstrakt Forlag.

Kristiansen, H. H. (2013): Hinduisme i religionsdidaktikken. En kvalitativ studie av forholdet mellom norske loereverkframstillinger av hinduisme, og hvordan unge norsk-tamilske hinduer forstår og uttrykker troen sin. [Hinduism in religious education]. Master Thesis. Oslo: University of Oslo.

Kvamme, O. A., Lindhardt, E. M., \& Steineger, A. (2008). I samme verden. Religion og etikk (2 ed.). Oslo: Cappelen Damm.

Kvamme, O. A., Lindhardt, E. M., \& Steineger, A. (2013). I samme verden. Religion og etikk, vg3. Oslo: CappelenDamm.

Leirvik, O. (2002). Islamsk etikk : ei idéhistorie. Oslo: Universitetsforlaget.

Leirvik, O. (2007). Religionspluralisme : mangfald, konflikt og dialog i Norge. Oslo: Pax.

Lippe, M. v. d. (2008). To believe or not to Believe: Young People's Perceptions and Experiences of Religion and Religious Education in Norway. In T. Knauth, D., P. Jozsa, G. Bertram-Troost \& J. Ipgrave (Eds.), Encountering Religious Pluralism in School and Society. A Qualitative Study of Teenage perspectives in Europe (pp. 149-171). Münster: Waxmann.

Lippe, M. v. d. (2011). Reality Can Bite: Perspectives of Young People on the Role of Religion in Their World. Nordidactica - Journal of Humanities and Social Science Education, 1(2), 15-34.

Moulin, D. (2011). Giving voice to 'the silent minority': the experience of religious students in secondary school religious education lessons. British Journal of Religious Education, 33(3), 313-326.

Nesbitt, E. (1998). Bridging the Gap between Young People's Experience of their Religious Traditions at Home and School: The Contribution of Ethnographic Research. British Journal of Religious Education, 20(2), 102-114.

Nesbitt, E. (2004). Intercultural Education. Ethnographic and Religious Approaches. Eastborne: Sussex Academic Press.

Nicolaisen, T. (2009). Hindu Children's Attitudes to Identity Constructs and Diversity: A Challenge for Norwegian Religious Education (RE)? In G. Skeie (Ed.), Religious Diversity and Education (pp. 181-195). Münster: Waxmann.

Nicolaisen, T. (2012). Corresponding values and colonising discourses: situating 'Hindu children' and their values in relation to hegemonic Norwegian discourses about religious education. British Journal of Religious Education, 34(3), 231-245.

Nicolaisen, T. (2013). Hindubarn i grunnskolens religions- og livssynsundervisning. Egengjøring, andregjøring og normalitet. $\mathrm{PhD}$. Oslo: University of Oslo. 
RE-curriculum. (2006). Religion and ethics - common core subject in programme for general studies. Upper Secondary. Oslo: Department of Education and Research.

Robson, G. (1995). Christians. Oxford: Heinemann Educational Publishers.

Samdal, A. G. (2013): En kvalitativ studie om forholdet mellom unge muslimers tro og fremstillingen som gis i religion- og etikkfagets laerebøker $i$ den videregående skolen [A qualitative study of the relationship between young Muslims' faith and the presentations given in religious education textbooks in upper secondary school]. Master Thesis. Oslo: University of Oslo.

Skrunes, N. (2010). Laerebokforskning. En eksplorerende presentasjon med sarlig fokus på Kristendomskunnskap, KRL og Religion og etikk. Oslo: Abstrakt Forlag.

Strandhagen, I. J. (2008). Unge sjiamuslimer i Oslo: om religiøs identitet, individualisering og forholdet til transnasjonal autoritet. Master thesis. Oslo: University of Oslo.

Thobro, S. A. (2008). Representasjoner av buddhisme og hinduisme: en diskursanalyse $i$ postkolonialt perspektiv av laerebøker i religionsfaget for gymnas/videregående skole. Master thesis. Bergen: University of Bergen.

Vogt, K. (2000). Islam på norsk: moskeer og islamske organisasjoner i Norge. Oslo: Cappelen.

Østberg, S. (1998). Pakistani children in Oslo: Islamic nurture in a secular context. Warwick: University of Warwick.

Østberg, S. (2003). Muslim i Norge. Religion og hverdagsliv blant unge norsk-pakistanere. Oslo: Universitetsforlaget. 